\title{
Observations on Renibacterium salmoninarum and the salmonid egg
}

\author{
David W. Bruno \& Alan L. S. Munro \\ Department of Agriculture and Fisheries for Scotland, Marine Laboratory, Victoria Road, Aberdeen AB9 8DB, Scotland
}

\begin{abstract}
Renibacterium salmoninarum cells were located entering the developing oogonia of experimentally infected juvenile rainbow trout Salmo gairdneri. These cells appeared to be viable. $R$. salmoninarum was cultured from the surface and contents of eggs from a mature Atlantic salmon Salmo salar even though the eggs had been bathed during water-hardening in erythromycin phosphate, penicillin or proflavin. No bacteria were detected in the fry hatched from these infected eggs.
\end{abstract}

\section{INTRODUCTION}

Vertical transmission of Renibacterium salmoninarum was first postulated to account for outbreaks of bacterial kidney disease (BKD) in brook trout Salvelinus fontinalis by Allison (1958). The disease occurred at a site previously free of BKD and followed the transfer of eggs from a hatchery where $\mathrm{BKD}$ had been enzootic for many years.

The first experimental evidence of vertical transmission was reported by Bullock et al. (1978). These authors noted that the severity of disease in fingerling chinook salmon Oncorhynchus tschawytscha was only reduced after disinfection with $100 \mathrm{mg} \mathrm{l}^{-1}$ iodine for $15 \mathrm{~min}$, even though it had been established that bathing Renibacterium salmoninarum in $25 \mathrm{mg} \mathrm{l}^{-1}$ iodine for $5 \mathrm{~min}$ killed this bacterium in vitro (Ross \& Smith 1978). It was concluded that $R$. salmoninarum could be transmitted with eggs, despite disinfection, but the nature of the egg-pathogen association was not speculated on (Bullock et al. 1978).

Recently, it was demonstrated that Renibacterium salmoninarum can occur within mature eggs of coho salmon (Oncorhynchus kisutch) and that bathing these eggs in iodine fails to reduce the prevalence of intraovum infection (Evelyn et al. 1984a).

The present study was undertaken to determine the efficacy of salmon egg disinfection against Renibacterium salmoninarum using compounds other than iodine and to establish if infection occurs in immature oogonia of rainbow trout Salmo gairdneri.

\section{MATERIALS AND METHODS}

Rainbow trout (mean weight $20 \mathrm{~g}$, mean length $12 \mathrm{~cm}$ ) were collected from a Scottish fish farm supplied with artesian water. There was no history of BKD at this farm over $7 \mathrm{yr}$ of testing. The fish were moved to the laboratory and held at $12{ }^{\circ} \mathrm{C}$ for $3 \mathrm{wk}$ before experimentation. Renibacterium salmoninarum (ATCC 33209, Sanders \& Fryer 1980) was harvested from Mueller-Hinton medium supplemented with $0.1 \%$ cysteine hydrochloride $(\mathrm{MH}+\mathrm{C})$ during the logarithmic growth phase. Following anaesthesia, 150 trout were experimentally infected with an intraperitoneal (ip) injection of $0.1 \mathrm{ml}$ of a peptone-saline suspension containing $2.7 \times 10^{7} R$. salmoninarum. During the $5 \mathrm{wk}$ experimental period, tissue samples were regularly obtained, fixed in a buffered formal saline, and processed for light microscopy. Ovarian tissue was removed attached to the swim bladder. Histological sections were prepared and stained using Gram and Lillies allochrome methods (Bruno \& Munro 1982).

An Atlantic salmon (weight $2.4 \mathrm{~kg}$ ), returning to spawn in the River Dee, Aberdeenshire, was transported to the laboratory. Following anaesthesia a rectal swab was obtained and cultured on $\mathrm{MH}+\mathrm{C}$. The fish was injected ip with $5 \mathrm{ml}$ of a Renibacterium salmoninarum suspension $\left(5.4 \times 10^{7}\right.$ bacteria $\left.\mathrm{ml}^{-1}\right)$ to surface-contaminate the eggs and placed in clean water to recover. Five d later the eggs were stripped and half were fertilized with milt collected from a 
returning male fish which was subsequently sampled for bacteriology and histology. Fertilized eggs were water-hardened for $1 \mathrm{~h}$ at $4{ }^{\circ} \mathrm{C}$, in 4 egg volumes of either tap water, or water containing erythromycin phosphate or penicillin (Table 1). At $2 \mathrm{wk}$ intervals, up to 4 mo post-hatching, 5 fry from each of the 4 groups were processed for histological examination by light microscopy.

The unfertilized eggs from the above fish were divided into approximately equal groups and bathed in one of the following: sterile water, or water containing erythromycin, penicillin or proflavin $(3,6$-diaminoacridine) (Table 1). The eggs were then rinsed in 3 changes of sterile water and each was transferred aseptically to a separate tube containing $5 \mathrm{ml} \mathrm{MH}+\mathrm{C}$ broth. The tubes were incubated at $15^{\circ} \mathrm{C}$. A Gramstained smear was prepared from the contents of any tube with bacterial growth. Gram-positive, non-motile, isolates were cultured on $\mathrm{MH}+\mathrm{C}$ medium and biochemical tests (catalase, DNA-ase, oxidase, amylase, haemolytic activity and gelatin liquefaction) were used to identify Renibacterium salmoninarum (Bruno \& Munro 1986). After $6 \mathrm{wk}$ the egg from any tube remaining sterile was removed from the $\mathrm{MH}+\mathrm{C}$ broth, washed twice in sterile water and transferred to fresh broth where it was broken using a pair of sterile forceps. Each tube was incubated for a further $6 \mathrm{wk}$ at $15^{\circ} \mathrm{C}$ and then subcultured on fresh $\mathrm{MH}+\mathrm{C}$ agar to test for bacterial growth. $R$. salmoninarum was identified as described.

\section{RESULTS}

Following the ip injection of Renibacterium salmoninarum into the juvenile rainbow trout, $75 \%$ of the fish developed a systemic disease characterised by granulomatous lesions in most tissues (Bruno 1984). $R$. salmoninarum was detected, using Gram and Lillies allochrome stains, in large numbers in the connective tissue surrounding the rainbow trout oogonia (arrowed, Fig. 1). From $28 \mathrm{~d}$ post infection, individual bacteria were recorded apparently entering the oogonia (arrowed, Fig. 2). In some cases, a heavy infection in the centre of the oogonia was recorded (Fig. 3).

Renibacterium salmoninarum was not cultured from the rectal sample taken from the wild-caught female Atlantic salmon, although given the origin of the fish it is conceivable it may have been infected. No external pathology was recorded in either of the wild, mature fish and there was no evidence of infection in the male fish. The number of $R$. salmoninarum cells on the surface of unfertilized Atlantic salmon eggs was reduced following disinfection but complete disinfection was not achieved (Table 2). A $1 \mathrm{~h}$ bath in proflavin was the most effective treatment, reducing the number of externally infected eggs by $25 \%$. R. salmoninarum was cultured on $\mathrm{MH}+\mathrm{C}$ from the interior of 3 surfacesterile unfertilized eggs representing $1.7 \%$ of the successfully surface-sterilized ova (Table 2).

Renibacterium salmoninarum was not detected in Gram or Lillies allochrome-stained sections prepared from the reared salmon fry. There was no difference in the hatch rates $(>95 \%)$ of the variously treated fertilized ova.

\section{DISCUSSION}

The results demonstrate that Renibacterium salmoninarum can infect developing oogonia within the ovary, and confirm that eggs resident in the body cavity may contain the pathogen.

This is the first evidence that Renibacterium salmoninarum can occur within immature oogonia, and the staining properties suggested that these bacteria were viable. Entry into the oogonia may be assisted by pinocytosis, the process by which large molecules are transported across the vitelline membrane (Hurley \& Fisher 1966, Longo \& Anderson 1974). Oogonia which are lightly infected early in maturation may well survive to reach maturity and serve as a source of recur-

Table 1. Treatment of unfertilized and fertilized salmon eggs with disinfectants and antibiotics

\begin{tabular}{|c|c|c|c|c|}
\hline \multirow[t]{2}{*}{ Treatment during water hardening } & \multicolumn{2}{|c|}{ Unfertilized eggs } & \multicolumn{2}{|c|}{ Fertilized eggs } \\
\hline & Bathing period & Concentration & Bathing period & Concentration \\
\hline Untreated & - & - & - & - \\
\hline Erythromycin phosphate & $30 \mathrm{~min}$ & $2 \mathrm{mg} \mathrm{l}^{-1}$ & $1 \mathrm{~h}$ & $2 \mathrm{mg} \mathrm{l}^{-1}$ \\
\hline Erythromycin phosphate + penicillin $\mathrm{G}$ & nt & & $1 \mathrm{~h}$ & $2 \mathrm{mg} \mathrm{l}^{-1}+50$ units $\mathrm{ml}^{-1}$ \\
\hline Penicillin G & $1 \mathrm{~h}$ & 50 units $\mathrm{ml}^{-1}$ & $1 \mathrm{~h}$ & 50 units $\mathrm{ml}^{-1}$ \\
\hline Proflavin & $30 \mathrm{~min}$ & $200 \mathrm{mg} \mathrm{l}^{-1}$ & nt & - \\
\hline Proflavin & $1 \mathrm{~h}$ & $200 \mathrm{mg} \mathrm{l}^{-1}$ & nt & - \\
\hline $\mathrm{nt}=$ not tested & & & & \\
\hline
\end{tabular}


Fig. 1. Salmo gairdneri. Lillies allochrome-stained section through an immature ovary from rainbow trout showing the presence of Renibacterium salmoninarum in connective tissue between the oocytes (arrowed), $\times 360$

Fig. 2. Salmo gairdneri. Lillies allochrome-stained section showing the entry of Renibacterium salmoninarum (arrowed) into an immature oocyte of rainbow trout, $\times 1440$

Fig. 3. Salmo gairdneri. Lillies allochrome-stained section showing $R e$ nibacterium salmoninarum (arrowed) within the immature oocyte, $\times 1440$
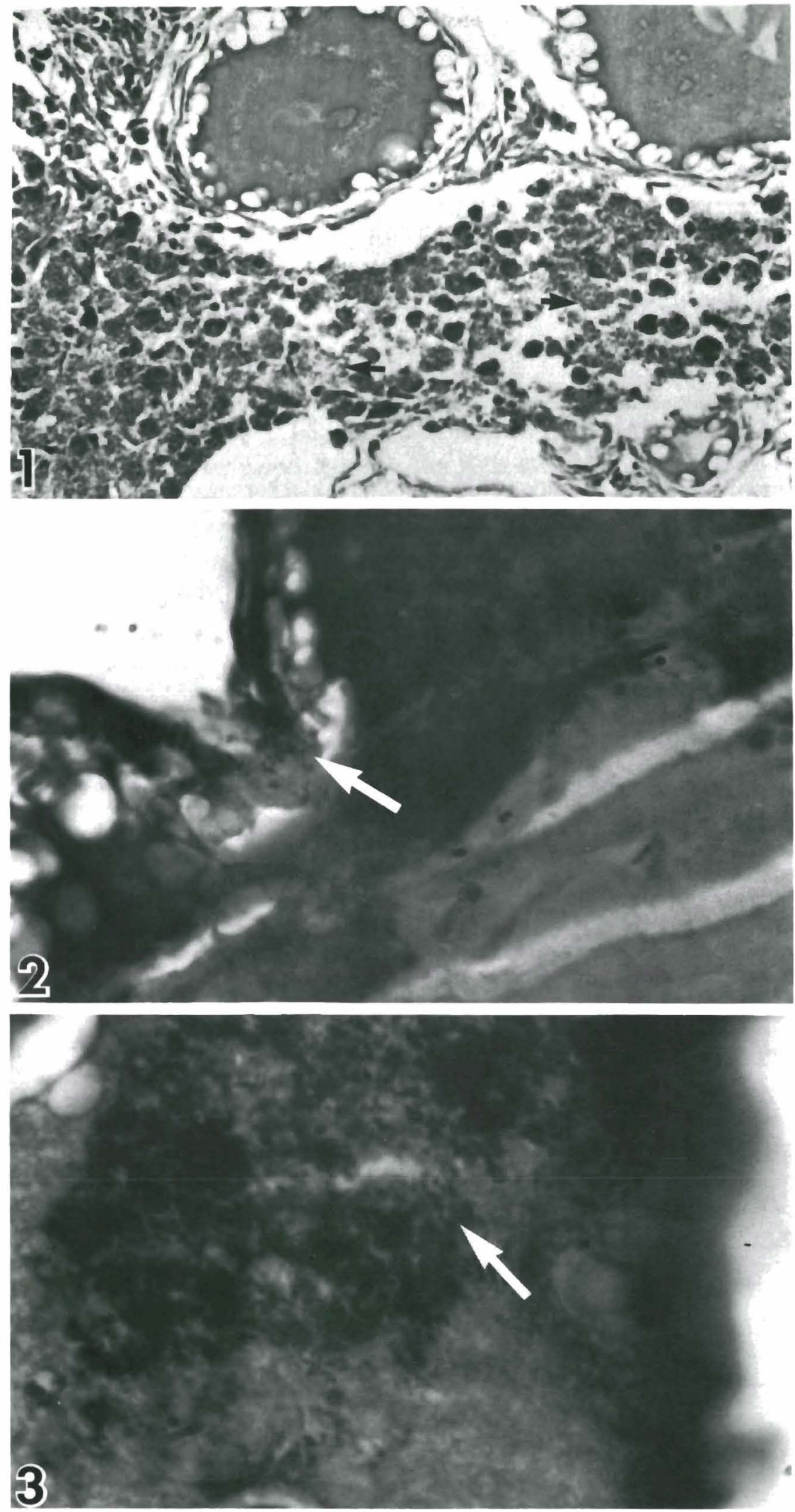
Table 2. Efficacy of egg disinfection and the recovery of Renibacterium salmoninarum from infected Atlantic salmon eggs

\begin{tabular}{|c|c|c|c|c|}
\hline Treatment & & $\begin{array}{l}\text { Number of unfertilized } \\
\text { eggs with surface- } \\
\text { contaminating } \\
\text { R. salmoninarum } \\
\text { per number tested }\end{array}$ & $\begin{array}{l}\% \text { eggs found } \\
\text { surface-sterile }\end{array}$ & $\begin{array}{c}\text { Number of surface- } \\
\text { sterile eggs yielding } \\
\text { growth of } \\
\text { R. salmoninarum }\end{array}$ \\
\hline Untreated & & $19 / 50$ & 62 & 0 \\
\hline Erythromycin phosphate & $(30 \mathrm{~min})$ & $18 / 45$ & 60 & 0 \\
\hline Penicillin & $(1 \mathrm{~h})$ & $13 / 45$ & 71 & 1 \\
\hline Proflavin & $(30 \mathrm{~min})$ & $26 / 80$ & 67 & 1 \\
\hline Proflavin & $(1 \mathrm{~h})$ & $5 / 40$ & 87 & 1 \\
\hline
\end{tabular}

rent infection as noted. However, the fate of heavily infected oogonia must be in question.

Renibacterium salmoninarum was cultured from the egg contents of a relatively low proportion $(1.7 \%)$ of the successfully surface-sterilized eggs. In contrast, Evelyn et al. (1984a) reported an intra-ovum infection rate as high as $15 \%$ in naturally infected coho salmon, perhaps the result of a longer egg-pathogen contact time. A natural infection may have accounted for the intra-ovum infections noted in our experiment. However, it is more likely that the injected bacterium was the source of the infection because BKD has not been recorded in wild broodstock from the River Dee in recent years (Bruno 1984).

Passage of Renibacterium salmoninarum across the chorion into the mature or near-mature egg could conceivably occur by 2 routes: the micropyle and the numerous pore canals (see Stehr \& Hawkes 1979). With the former, passage would be dependent on the nonmotile bacterium reaching the micropyle before fertilization, because fertilization occludes the micropyle, preventing access to the perivitelline area (Kobayashi \& Yamomoto 1981). Entry via pore canals might be facilitated, prior to ovulation, by the oocyte extensions (microvilli) which traverse the pore canals and transport nutrients from the follicle cells to the oocyte (Stehr \& Hawkes 1979). Following ovulation, the pore canals become plugged. The timing and completeness of this process is uncertain (Stehr \& Hawkes 1979), but any pores remaining open in recently ovulated eggs could provide the pathogen with access to the interior of the egg. However, once the egg is activated water passes from the environment through the chorion to form a fluid-filled perivitelline space (Hurley \& Fisher 1966, Stehr \& Hawkes 1979). The resulting 'hardened egg' is resistant not only to mechanical damage but also infection, suggesting that at this stage all pores and the micropyle are closed at least sufficiently to prevent the entry of bacteria. From the available histological evidence (Evelyn et al. 1984a) it appears that $R$. salmoninarum gains entry to the yolk where it is presumably protected from the effects of disinfectants. The mechanism by which $R$. salmoninarum reaches the yolk is not known. Evelyn et al. (1984a) speculated that the $R$. salmoninarum was derived from the heavily infected coelomic fluid that surrounded the eggs following ovulation, but the possibility that the infections occurred early in oogenesis could not be ruled out.

An alternative survival mechanism for Renibacterium salmoninarum is persistence on the surface of ova during incubation followed by later infection of the hatched fry. However, in this study less than $40 \%$ of the salmon eggs were infected externally despite a significant challenge. This may have been due to the short egg-pathogen contact which may have precluded the formation of a durable association of the pathogen with the egg surface. Another persistence mechanism could involve excretion of the pathogen into the environment along with eggs at the time of spawning - the excretion occurring via the abdominal pores (George et al. 1982) or the vent. Austin \& Rayment (1985) recovered viable $R$. salmoninarum from fish tank sediments $21 \mathrm{~d}$ after the last fish in the tank had died of BKD. More important, viable $R$. salmoninarum has been re-isolated by Bruno (1984) on $\mathrm{MH}+\mathrm{C}$ medium after $13 \mathrm{wk}$ in saline/peptone at $15^{\circ} \mathrm{C}$, proving that this bacterium can retain its viability external to the host for a period at least equivalent to the incubation period of the eggs. The apparent lack of cell division in saline-peptone recorded by this author may also contribute to survival within or on ova.

Cultures of Renibacterium salmoninarum were recovered from within unfertilized eggs that had been surface disinfected. We conclude that this bacterium occupies a site not accessible to the disinfectants and compounds listed in Table 1, or to erythromycin phosphate, penicillin (Evelyn et al. 1984a), benzalkonium chloride or thimerosal (Evelyn et al. 1984b). The only complete disinfection of the contaminated egg surface was established during post-water hardening by Evelyn et al. (1984a) who used $500 \mathrm{mg} \mathrm{l}^{-1}$ iodine for $1 \mathrm{~h}$. Interestingly, this concentration is higher than that normally adopted for hatchery use or that recommended by Canadian authorities $\left(100 \mathrm{mg} \mathrm{l}^{-1}\right.$ for 
$10 \mathrm{~min}$ ) for disinfecting eggs (Department of Fisheries and Oceans 1984).

The generally unsatisfactory performance of these disinfection protocols leads to the conclusion that such treatments cannot be safely relied upon to disinfect ova from infected broodstock. The belief that ova can be satisfactorily disinfected has likely resulted in the introduction of BKD into several countries (Ghittino et al. 1977, Hoffman et al. 1984).

\section{LITERATURE CITED}

Allison, L. N. (1958). Multiple sulfa therapy of kidney disease among brook trout. Prog. Fish-Cult. 20:66-68

Austin, B., Rayment, J. N. (1985). Epizootiology of Renibacterium salmininarum, the causal agent of bacterial kidney disease in salmonid fish. J. Fish Dis. 8: 505-509

Bruno, D. W. (1984). Studies on bacterial kidney disease in Salmo gairdneri Richardson and Salmo salar L. Ph. D. thesis, University of Aberdeen

Bruno, D. W., Munro, A. L. S. (1982). Detection of the causative agent of bacterial kidney disease. Bull. Eur. Ass. Fish Path. 2: $10-12$

Bruno, D. W., Munro, A. L. S. (1986). Uniformity in the biochemical properties of Renibacterium salmoninarum isolates obtained from several sources. FEMS Microbiol. Lett. 33: 247-250

Bullock, G. L., Stuckey, H. M., Mulcahy, D. (1978). Coryaebacterial kidney disease: Egg transmission following iodophore disinfection. Fish Health News 7: 51-52

Department of Fisheries and Oceans. (1984). Fish health protection regulations: manual of compliance. Fish. Mar. Serv. Misc. Spec. Publ. 31 (Revised): 1-43

Evelyn, T. P. T., Ketcheson, J. E., Prosperi-Porta, L. (1984a). Further evidence for the presence of Renibacterium salmoninarum in salmonid eggs and the failure of providone- iodine to reduce the intra-ovum infection rate in waterhardened eggs. J. Fish Dis. 7: 173-182

Evelyn, T. P. T., Prosperi-Porta, L., Ketcheson, J. E. (1984b). The salmonid egg as a vector of the kidney disease bacterium, Renibacterium salmoninarum. In: Fish Diseases Fourth COPRAQ Session, Cadiz, Spain, p. 111-117

George, C. J., Ellis, A. E., Bruno, D. W. (1982). On rememberance of the abdominal pores in rainbow trout, Salmo gairdneri Richardson, and some other salmonid spp. J. Fish Biol. 21: 643-647

Ghittino, P., Andruetto, S., Viglianni, E. (1977). Recent findings in trout kidney pathology in Italy. Bull. Off. int. Epiz. 87: 491-493

Hoffman, R., Popp, W., van de Graaff, S. (1984). Atypical BKD predominantly causing ocular and skin lesions. Bull. Eur. Ass. Fish Path. 4: 7-9

Hurley, D. A., Fisher, K. C. (1966). The structure and development of the external membrane in young eggs of the brook trout, Salvelinus fontinalis (Mitchill). Can. J. Zool. 44: 173-190

Kobayashi, W., Yamomoto, T. S. (1981). Fine structure of the micropylar apparatus of the chum salmon egg, with a discussion of the mechanism for blocking polyspermy. J. exp. Zool. 217: 265-275

Longo, F. G., Anderson, E. (1974). The onset of development. 1. Gametogenesis. In: Lash, J., Whittaker, J. R. (ed.) Concepts of development. Sinuaer Associates Inc., Stamford, Connecticut, p. $3-47$

Ross, A. J., Smith, C. A. (1978). Effect of two iodophors on bacterial and fungal fish pathogens. J. Fish. Res. Bd Can. 29: $1359-1361$

Sanders, J. E., Fryer, J. L. (1980). Renibacterium salmoninarum gen. nov., sp. nov., the causative agent of bacterial kidney disease in salmonid fishes. Int. J. Syst. Bact. 30: 496-502

Stehr, C. M., Hawkes, J. W. (1979). The comparative ultrastructure of the egg membrane and associated pore structures in the starry flounder, Platichthys stellatus (Pallas), and pink salmon, Oncorhynchus gorbuscha (Walbaum). Cell Tissue Res. 202: 347-356 